\title{
ANAESTHETIC MANAGEMENT OF PHAEOCHROMOCYTOMA
}

\author{
Vasilios Pratillas and Margaret G. Pratila
}

Phaeochromocytoma is a relatively rare, most often histologically benign tumour of the sympathetic nervous system which secretes excessive quantities of the catecholamines epinephrine and norepinephrine into the bloodstream. Ninety per cent of these tumours are found in the adrenals (right more often than left); eight per cent in chromaffin tissue within the abdomen and only two per cent extra-abdominally in the thorax or neck.' About 10 per cent are bilateral or multiple (common in children) and between six and ten per cent are malignant. ${ }^{2}$

Mortality following surgery was 25 to 45 per cent before $1950 .{ }^{3}$ With improvement in preoperative, operative and postoperative care, mortality ranges from three per cent in uncomplicated cases to 20 per cent in those that are complicated. ${ }^{4}$

\section{Physiology}

Chromaffin cells produce catecholamines, three of which occur in the body (dopamine, norepinephrine, and epinephrine). Norepinephrine is the neurohumoral transmitter of the adrenergic nervous system. Its main biosynthesis occurs within the postganglionic sympathetic neurons. Figures 1 and 2 show formation and catabolis $m$ of norepinephrine. Epinephrine is synthesized and stored in the adrenal medulla in a similar manner. The enzyme $\mathrm{N}$-methyl-transferase which is necessary for conversion of norepinephrine to epinephrine is found only in the adrenal medulla in man. 5

\section{Clinical findings}

The derangements seen in phaeochromocytoma are accounted for by the known physiological effects of epinephrine and norepinephrine and include hypertension, alterations in pulse rate and a hypermetabolic state.

1. Hypertension: Very severe hypertensive cardiovascular disease can be produced by phaeochromocytomata. Convulsions can occur

Vasilios Pratilas, M.D., Assistant Clinical Professor, and Margaret G. Pratila, M.D., Assistant Clinical Professor, Department of Anesthesiology, Mount Sinai School of Medicine, City University of New York, New York, N.Y. 10029, U.S.A.

Canad. Anaesth. Soc. J., vol. 26, no. 4, July 1979

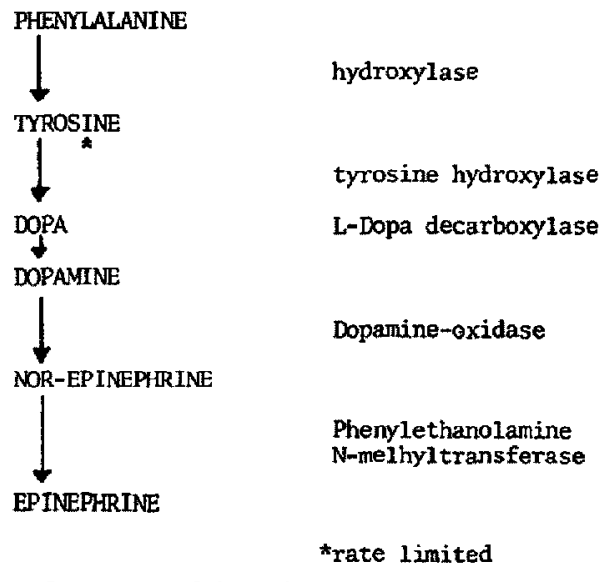

FIGURE I Schematic representation of the metabolic pathway for production of norepinephrine and epinephrine.

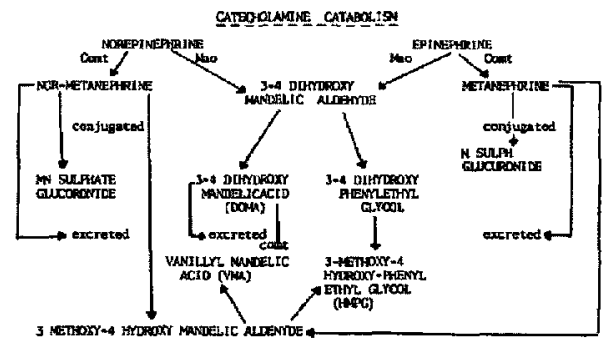

FIGURE 2 Schematic representation of the pathways for catecholamine catabolism.

from hypertensive encephalopathy. Hypertension can be sustained or paroxysmal. A few patients are normotensive and have no attacks. but on exposure to the stress of operation or parturition will suddenly liberate enormous amounts of catecholamines from their tumours with resultant very high blood pressure or cardiac arrest.

2. Alterations in pulse rate: The catecholamines have characteristic effects on the pulse. Norepinephrine causes slowing while epinephrine produces tachycardia which can be marked. 
3. Hypermetabolic states produced by the catecholamines can be mistaken for thyrotoxic or anxiety states. Epinephrine and to a lesser extent norepinephrine cause glycogenolysis, hyperglycatemia, and glycosuria.

Gastrointestinal haemorrhage, ${ }^{6}$ ileal infarction and ileus' have been reported. possibly as a result of vascular changes associated with intense valsoconstriction. Gupta ${ }^{8}$ has reported an increased incidence of myocardial infarction.

\section{Diagnosis}

Diagnosis cannot be made on the basis of symptoms alone. Similar symptoms may be found in anxiety states, hyperventilation syndrome, paroxysmal tachycardia, migraine headache. periodic cerebrovascular insufficiency, hyperthyroidism. menopause, and others.9

A high index of suspicion should be present, however, and urinary metabolites of epinephrine and norepinephrine should be sought in all patients presenting with one or more of the following: ${ }^{10}$

1. Hypertension (less than 5 in 1.000 have phaeochromocytoma). ${ }^{11}$

2. Paroxysmal symptoms.

3. Unexplained hypermetabolic state.

4. Inappropriate cardiovascular response to trauma, partuition, anaesthesia.

5. Neurocutaneous syndrome.

6. Familial history of phaeochromocytoma.

7. Multiple endocrine neoplasia - Type II.

The, diagnosis is based mainly on laboratory findings. Excretion of vanillylmandelic acid (VMA). studied by bi-directional paper or gasliquid chromatographic methods, requires only a random urine specimen and is not influenced by most commonly used drugs or by diet. ${ }^{12}$ In the absence of coma or a tumour of neural crest origin, VMA excretion in excess of $5 \mu \mathrm{g} / \mathrm{mg}$ creatinine is extremely rare.

Measurement of total metanephrines can be done by a reliable photometric method. ${ }^{13.14}$ Gitlow, et al." "have reported, however, that severe stress conditions may also result in elevation of total metanephrine excretion. VMA excretion is, however. usually normal in these patients.

Pertsemlides, et $a l^{15}$ have stated that excretion by a non-comatose patient of excessive quantities of two catecholamine metabolites in separate urine specimens is diagnostic for phaeochromocytoma.

\section{Treatment}

Because there is a high incidence of malignancy in these tumours, treatment must be surgical, but only after adequate medical stabilization. A complicating metastatic neoplasm or pregnancy are the only reasons for delaying operation.

Treatment may be divided into preoperative, intraoperative, and postoperative phases.

\section{Preoperarive (Table I)}

$A$. Alpha receptor blockade has improved the management of these patients with phaeochromocytoma. Two drugs are in common use:

1. Phenoxybenzamine is a potent $\alpha$-addrenergic receptor blocking agent, given orally or intravenously. It is long-acting with a half-life of over 24 hours. It is started in doses of $20 \mathrm{mg} /$ day by mouth for an adult, with monitoring of blood pressure supine and standing. It is increased by $10 \mathrm{mg}$ increments daily until the patient begins to experience orthostatic hypotension. The dose is then reduced $10 \mathrm{mg}$ and continued at that level.

2. Phentolamine $\mathrm{HCl}$ is a short-acting alpha blocker. We prefer to use this agent if surgery is scheduled, because it is short acting. Phentolamine is prepared by diluting $5-10 \mathrm{mg}$ in $500 \mathrm{ml}$ of five per cent dextrose in water. The infusion rate required for adequate adrenolytic protection may vary from $2-60 \mathrm{mg} /$ hour (or $30-1,000 \mu \mathrm{g} / \mathrm{min}$ ute). ${ }^{\text {is }}$

$B$. Beta adrenergic blockers have been used in the preoperative and operative period, as reported by many authors. ${ }^{16-20}$ It is stated that the $\beta$-blocking agents protect against dysrhythmias and permit reduction in the amount of $\alpha$-blocking drugs necessary to control blood-pressure. 17 The use of $\beta$-blocking drugs has also been suggested where tachyphylaxis to $\alpha$-adrenergic-blocking agents occurs ${ }^{18} \beta$-adrenergic blockade should only be used when $\alpha$-blockade is established. $\beta$-blockade alone may cause a marked rise in the total peripheral resistance secondary to unopposed $\alpha$-adrenergic activity. ${ }^{19.20}$ We reserve the $\beta$-blocking agents to two circumstances in the preoperative management of phacochromocytoma. They are used when there are frequent ventricular dysrhythmias and in cases of sustained tachycardia, generally in the range of 140 beats per minute in the adult and a lesser rate in the elderly.

\section{During operation}

Virtually all commonly used premedicant 
TABLE I

Preoperative Drugs

\begin{tabular}{|c|c|c|}
\hline Drug & Dose & Effect \\
\hline Phenoxybenzamine & $\begin{array}{l}20 \mathrm{mg} / \text { day p.o. ( } \mathrm{max} .160 \mathrm{mg} / \mathrm{day} \text { ). Given to } \\
10 \mathrm{mg} \text { below dose producing orthostatic } \\
\text { hypotension }\end{array}$ & $\begin{array}{l}\alpha \text {-adrenergic blockade } \\
\text { Long acting }\end{array}$ \\
\hline Phentolamine & $\begin{array}{l}\text { Dilute } 5-10 \mathrm{mg} \text { in } 500 \mathrm{ml} \mathrm{D5W} \text { i.v. } 2-60 \mathrm{mg} / \mathrm{hr} \\
(30 / 1000 \mu \mathrm{g} / \mathrm{min})\end{array}$ & $\begin{array}{l}\alpha \text {-adrenergic blockade } \\
\text { Short acting }\end{array}$ \\
\hline Chlorpromazine & $50 \mathrm{mg} \mathrm{q} 6 / \mathrm{hr}$. p.o. 3 preop. days & $\begin{array}{l}\text { Adrenergic blocking } \\
\text { Antidysrhythmic } \\
\text { Sedative }\end{array}$ \\
\hline Propanolol & 10-40 mg p.o. t.i.d. & $\begin{array}{l}\beta \text {-adrenergic blockade } \\
\text { Only to control dysrhythmia } \\
\text { or sinus tach. (prior } \alpha \text {-block- } \\
\text { ade) }\end{array}$ \\
\hline$\alpha$-methylparatyrosine & $1.5-3 \mathrm{~g} /$ day p.o. & $\begin{array}{l}\text { Prevents catecholamine } \\
\text { synthesis } \\
\text { Parkinsonism }\end{array}$ \\
\hline
\end{tabular}

drugs have been used successfully in the management of patients with phaeochromocytoma (Table II). Atropine is usually omitted as tachycardia may occur, although opinion is not unanimous. ${ }^{21}$

Anaesthetic management of the patient undergoing surgical removal of a phaeochromocytoma is directed towards control of the cardiovascular system. Close monitoring is an absolute necessity and includes the electrocardiogram, central venous pressure, arterial line for continuous arterial pressure readings, and a Swan-Ganz catheter. ${ }^{22}$ Preoperative excess catecholamine output leads to a chronically constricted blood volume. Rehydration is an essential part of the preoperative preparation of the patient. Measurement of pulmonary capillary wedge pressure helps in assessment of intravascular volume replacement. Enormous swings in blood pressure can occur during the operation. Changes in vascular resistance can be rapidly monitored and appropriate therapy instituted.

Induction with sodium thiopentone has been used in almost every case of phaeochromocytoma reported. Virtually all inhalation anaesthetic agents have been used for the maintenance of anaesthesia. Uncontrolled hypertension, severe hypotension and cardiac dysrhythmias are the problems which must be anticipated. While hypertension may occur during manipulation of the tumour, it may also be precipitated by increased intra-abdominal pressure on transfer to the operating table, coughing during tracheal intubation or surgical preparation. ${ }^{23}$ For this rea- son an adequate depth of anaesthesia is necessary during all these manoeuvres.

Gould and Perry have reported from the Mayo Clinic on the results in patients anaesthetized

TABLE II

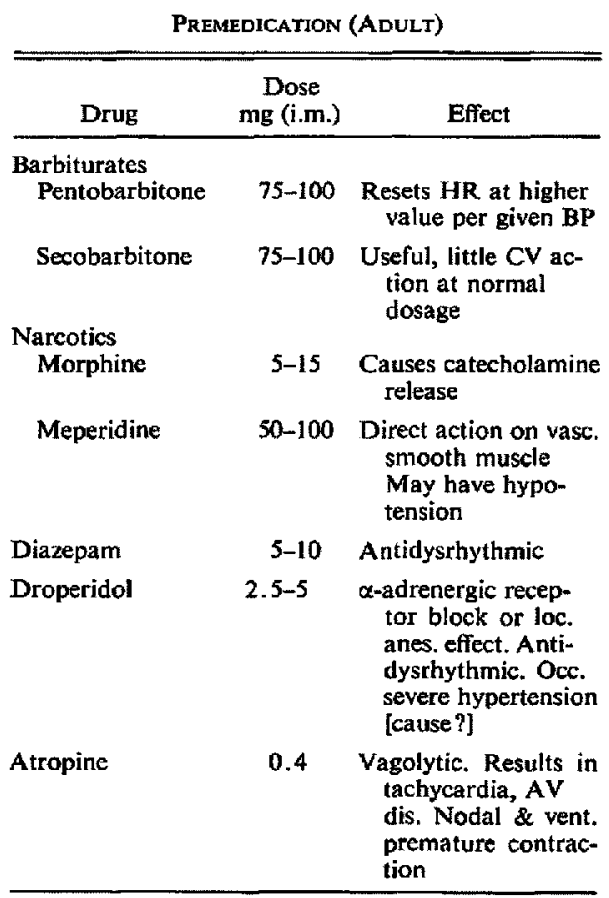


TABLE III

MUSCLE RELAXANTS

\begin{tabular}{|c|c|c|c|}
\hline Drug & Effect & Dysrhythmia & Blood pressure \\
\hline Succinylcholine & $\begin{array}{l}\downarrow \text { cardiac excitability threshold } \\
\text { Sympathetic post-ganglionic } \\
\text { stimulation }\end{array}$ & $\begin{array}{l}\text { Bradycardia } \\
\text { Sinus arrest } \\
\text { Supraventricular \& ventricular }\end{array}$ & Elevated \\
\hline d-tubo-curare & $\begin{array}{l}\text { Ganglionic blockade } \\
\text { Prevents SDC produced } \\
\text { dysrhythmias }\end{array}$ & & $\begin{array}{l}\text { Releases histamine } \\
\text { (tumor activity may be } \\
\text { excited) } \\
\text { Large doses-ganglion } \\
\text { blockade may cause } \\
\downarrow \mathrm{BP}\end{array}$ \\
\hline Pancuronium & $\begin{array}{l}\text { No stimulation of tumor activity } \\
\text { No ganglion blockade or } \\
\text { histamine release }\end{array}$ & $\begin{array}{l}\text { Vagolytic } \\
\text { May have tachycardia }\end{array}$ & Elevated \\
\hline Gallamine & $\begin{array}{l}\text { Anticholinergic } \\
\text { ? } \beta \text {-adrenergic stimulant }\end{array}$ & Tachycardia & Elevated \\
\hline
\end{tabular}

with diethyl ether. ${ }^{24}$ Although diethyl ether is alleged to liberate catecholamines, ${ }^{25}$ tachycardia and cardiac dysthythmias were not a major problem when this was the primary agent.

Halothane, ${ }^{26}$ methoxyflurane, ${ }^{27}$ and enflurane ${ }^{28}$ all depress the spontaneous release of catecholamines from the adrenal medulla and the secretion evoked by splanchnic nerve stimulation. Zahed, et $a .^{29}$ have noted that enflurane, methoxyfurane and fluroxene do not sensitize the heart to catecholamine-induced dysrhythmias. Only the halogenated hydrocarbon halothane lowered the dysrhythmic threshold doses for epinephrine.

Enflurane has been used for the removal of phaeochromocytoma in recent years. ${ }^{21}$ Reports have shown a decreased incidence of dysrhythmia during operation. Kopriva and Eltringham $^{30}$ reported only nodal premature contractions during manipulation of the adrenal glands.

Many authors have reported favourably on the use of neuroleptanaesthesia with a combination of droperidol and fentanyl for removal of phaeochromocytoma. ${ }^{31.33}$ Droperidol antagonizes the pressor effects of the catecholamines and prevents dysrhythmia, ${ }^{34}$ either by alpha blockade or local antesthetic action ${ }^{36}$ while fentanyl has been shown to have an $\alpha$-adrenergic blocking effect. Sumikawa and Amakata ${ }^{38}$ have, however, described a marked increased in blood pressure following droperidol administration in a patient with phaeochromocyloma.

Neuromuscular blocking agents used for surgery for phaeochromocytoma have included succinylcholine, d-tubocurare and pancuronium
(Table III). Gallamine has been generally avoided because of its anticholinergic action. Brown and Crout $^{40}$ also believe it has a direct $\beta$-adrenergic stimulating effect on cardiac receptors. Galindo and Davis'1 have shown that succinylcholine lowers the cardiac excitability threshold.

Mathias and Evans-Prosser ${ }^{42}$ demonstrated that small amounts of d-tubocurare block dysthythmias induced by succinylcholine. Katz and Bigger ${ }^{63}$ believe this is due to its ganglionblocking property. Tumour activity may be excited by d-tubocurare through its liberation of histamine. Clinically, however, both succinylcholine and tubocurare have been used successfully. Pancuronium does not produce histamine release $^{44}$ and has no ganglion blocking effect in man.

Both lidocaine and $\beta$-adrenergic blocking agents have been used for the treatment of dysrhythmia during surgery for phaeochromocytoma. They are both effective although their modes of action probably differ. Propranolol may slow recovery of cardiovascular stability in the postoperative period and most authors prefer to use lidocaine (Table IV).

Phentolamine is the drug most often used for management of the hypertensive episodes during the stress of anaesthesia and operation. Approximately five times the preoperative dose is usually needed during the critical phases of the operation. Sodium nitroprusside has also been used during operation for treatment of increases in blood pressure ${ }^{31,32}$ Its action is immediate and directly on the vessel wall. Recovery occurs in one to two minutes. 
TABLE IV

INTRAOPERATIVE DRUGS

\begin{tabular}{|c|c|c|}
\hline Drug & Dose & Effect \\
\hline Phentolamine $\mathrm{HCl}$ & $\begin{array}{l}\text { Dilute } 25-50 \mathrm{mg} \text { in } 500 \mathrm{ml} \text { D } 5 \text { W } 10-300 \\
\mathrm{mg} / \mathrm{hr}(150-5000 \mu \mathrm{g} / \mathrm{min})\end{array}$ & $\begin{array}{l}\text { a-adrenergic blockade } \\
\text { Short acting } \\
\text { Control of BP }\end{array}$ \\
\hline Nitroprusside & $\begin{array}{l}0.5-1.5 \mu \mathrm{g} / \mathrm{kg} \mathrm{min} \text {. Total dose not to } \\
\text { exceed } 3-3.5 \mathrm{mg} / \mathrm{kg} \text { (or } 1 \mathrm{mg} / \mathrm{kg} \text { ?) }\end{array}$ & $\begin{array}{l}\text { Direct act on smooth muscle wall vessel } \\
\text { Very short acting } \\
\text { Generally } \uparrow \text { HR \& } \downarrow \text { BP }\end{array}$ \\
\hline Propranolol & 1-2 mg i.v. bolus ( $5 \mathrm{mg}$ maximum) & $\begin{array}{l}\text { B-adrenergic receptor blockade } \\
\text { Only to control dysrhythmia or sinus tach, }\end{array}$ \\
\hline Lidocaine & $1 \mathrm{mg} / \mathbf{k g ~ i , v . ~ b o l u s ~}$ & $\begin{array}{l}\uparrow \mathbf{K} \dagger \text { conductance membrane. Effective } \\
\text { against re-entry dysrhythmias }\end{array}$ \\
\hline
\end{tabular}

Following removal of the phaeochromocytoma, falls in circulatory catecholamine levels may result in hypotension. Rapid infusion of lactated Ringer's solution and/or blood is the treatment of choice, with careful cardiovascular monitoring. If vasopressors are needed, norepinephrine is favoured by most authors. ${ }^{17.46}$

Kumar and Zsigmond ${ }^{47}$ recently reported on their experiences with 34 patients with phaeochromocytoma. Two deaths which occurred were the result of acute myocardial failure which developed following a prolonged period of severe hypertension. They believe vasopressor therapy to be dangerous in these circumstances, as the failure may be due to active catecholamine myocarditis. They suggest the use of mechanical circulatory assistance by means of an aortic balloon pump to allow time for the myocardium to recover.

\section{Postopenative management}

Close monitoring is mandatory during the immediate postoperative period. Adequate urinary output is of far more importance than the level of the blood pressure itself.

Hypotension, tachycardia, and decreased urinary output may indicate inadequate correction of the blood volume deficit; an acute medical problem such as myocardial infarction, cardiac failure, sepsis or retroperitoneal bleeding.

\section{SUMMARY}

The incidence, mortality, physiology, clinical findings and diagnosis of phaeochromocytoma are reviewed. Treatment, after adequate medical stabilization, must be surgical because of the high incidence of malignancy. Alpha-adrenergic receptor blockade and $\beta$-adrenergic receptor block- ade in the preoperative period was discussed. Anaesthetic management of patients with phreochromocytoma requires close monitoring. Virtually all inhalational anaesthetic agents have been used in cases of phaeochromocytoma. Recent reports have favored enfiurane. The merits of neuroleptanzesthesia and the various muscle relaxants are also discussed. Most authors favour lidocaine over propranalol for management of dysrhythmias during operation. Phentolamine or sodium nitroprusside are used for hypertension during operation. Hypotension is treated by fluid replacement with nor-epinephrine if a vasopressor becomes necessary. Close monitoring is necessary in the postoperative period. Adequate urinary output is of more importance than actual blood pressure levels.

\section{RÉSUMÉ}

Différents aspects du phéochromocytome sont passés en revue; en particulier, l'incidence, la mortalité. les manifestations cliniques et le diagnostic. Etant donnée l'incidence élevée de malignité, le traitement chirurgical s'impose après stabilisation par une médication appropriée. Le blocage $\boldsymbol{\alpha}$-adrénergique et $\boldsymbol{\beta}$-adrénergique avant l'intervention est discuté. $L$ 'anesthésie exige un monitorage minutieux. A peu près tous les agents inhalatoires ont été employés mais de rapports récents favorisent l'enflurane. Les mérites de la neuroleptanesthésie et des différents myorésolutifs sont présentés. La plupart des auteurs favorisent la lidocaine sur le propanolol pour le contrôle per-opératoire des dysrythmies et la phentolamine ou le nitroprussiate de sodium pour l'hypertension. L'hypotension se traite par l'apport liquidien et la norépinéphrine si un vasopresseur devient nécessaire. La période post- 
opératoire demande un monitorage attentif. Un débit urinaire adéquat est plus important que la pression artérielle elle-même.

\section{REFERENCES}

1. Hume, D.M. Pheochromocytoma in the adult and in the child. Am. J. Surg. 99: 458-490 (1960).

2. Huebner, A.D. \& ReED, P.A. Secreting tumor chromatfin tissue. Ann. Surg. 158: 216-221 (1963).

3. APGar, V. \& Popper, E.M. Pheochromocytoma: anesthetic management during surgical treatment. Arch. Surg. 62: 634-648(1951).

4. Rimine, W.h., Chang, C.C., Van Heerden, J. A. ef al. Current management of pheochromocytoma. Ann. Surg. 179: 740-748(1974).

5. Axtarod, J. Methylation reactions in the formation and metabolism of catecholamines and other biogenic amines. Pharmocol. Rev, 18: 95-113 (1966).

6. Mil.ES, R.M. Pheochromocytoma - interesting experiences with three cases. Am. Surg. 149: 925-935 (1969).

7. CKUZ, S.R. \& COLWELL, J.A. Pheochromocytoma and ileus. J.A.M.A. 219: 1050-1051 (1972)

8. GUPTA. K.K. Phacochromocytoma and myoCardial infarction. Lancet. 281-282 (1975).

9. Priestley, J.T., Kvale, W.F., \& Gifford, R.W. Pheochromocytoma. Arch. Surg. 86: 778-790 (1963).

10. Gitlow, S.E., Pichel-Warner, R.R.. \& BerTANI. L.M. Catecholamines and indolamines in human disease. In The Thyroid and Biogenic Amines. Rall and Kopin (eds.) North-Holland Publishing Co. p. 644 (1972).

11. Gitlow, S.E., Pertsemlidis, D., \& Bertani. L.M. Management of patients with pheochromocytoma. Am. Heart J. 82: 557-567 (1971).

12. MCNEELEY, M.D.D. Drug interference with laboratory tests: pheochromocytoma. Drug therapy. |37-14| (1974).

13. Gitlow, S.E., Mendlowitz, M., \& Bertani, L.M. The biochemical techniques for detection and establishing the presence of pheochromocytoma. Am. J. Cardio. 26: 270 (1970).

14. Crout, J.R. Pisano, J.J. \& Sjoerdesma, A. Urinary excretion of catecholamines and their metabolites in pheochromocytoma. Am. Heart $J$. 6I: 375 (1961).

15. Pertsemlidis, D., Gitlow, S.E., Siegel, W. e $t$ al. Pheochromocytoma. Ann. Surg. 3: 376-385 (1969).

16. Crout, J.R. \& Brown, B.R., JR. The value of phenoxybenzamine and methoxyflurane. Anesthetic management of pheochromocytoma. Anesthesiology 30: 29-36 (1969).

17. Ross, E.J., Richard, B.N.C., Kaufman, L., et al. Preoperative and operative management of patients with phaeochromocytoma. Brit. Med. J. I: 191 (1967).

18. SAL.EM. M.R. \& IVANKovic. A.D. Management of phentolamine resistant phaeochromocytoma with $\beta$-adrenergic blockade. Brit. J. Anesth. 4l: 1087-1090 (1969).

19. Harrison, T.S., Bartlett, J.D. Ir., \& Seaton,
I.F. Current evaluation and management of pheochromocytoma. Ann. Surg. 168: 701 (1968).

20. EDELIST, G. Multiple anaesthetics in a patient with pheochromocytoma. Canad. Anaes. Soc. Jour. 22: 715-718(1975).

21. Janeczko, G.F., Ivankovich, A.D., Glisson, S.N., et al. Enflurance anesthesia for surgical removal of pheochromocytoma. Anesth. Analg. 56: 62-67(1977)

22. Darby, S. \& Prys-Roberts, C. Unusual presentation of phaeochromocyloma. Anaesthesia 31 : 913-916(1976).

23. Perry, L.B. \& Gould, A.B. JR. The anesthesia management of phaeochromocytoma: effect of preoperative adrenergic blocking drugs. Anesth. \& Analg. 51: $36-40$ (1972).

24. Gould, A.B. JR. \& Perky, L.B. The anesthetic management of pheochromocytoma cases involving nonexplosive techniques, metastasis tumors and multiple procedures. Anesth. \& Analg. 5I: 173-176 (1972).

25. Gothert, M., Bischoff, D., \& Dreivie, C. Einflus von inhalationsnarkotica auf die katecholamine sekretion aus dem Nebennieren mark in vivo. Anaesthesist 24: 19-26 (1975).

26. Gothert, M. \& DReyer, C. Inhibitory effect of halothane anesthesia on catecholamine release from the adrenal medualla. Naunym-Schmiedebergs Arch. Pharmcol. 227: 253-266 (1973).

27. Dreyer, C., Bischoff, D., \& Gothert, M. Ef. fects of methoxyflurane anesthesia on adrenal medullary catecholamine secretion. Anesthesiology 4l: 18-26(1974).

28. GOTHERT, M. \& WENDT, J. Inhibition of adrenal medullary catecholamines secretion. Anesthesiology 46: 400-410 (1977).

29. Zahed, B., Miletich, D.J. IVankovich, A.D. et al. Arrhythmic doses of epinephrine and dopamine during halothane, enflurane, methoxyfurane and fluroxene anesthesia in goats. Anesth. \& Analg. 56: 207-210(1977).

30. Kopriva, C.J. \& Eltringham, R. The use of enflurane during resection of a pheochromocytoma. Anesthesiology 4l: 399-400 (1974).

31. El-Naggar, M., Suerete, E.. \& Rosenthal., E. Sodium nitroprusside and lidocaine in the anaesthetic management of pheochromocytoma. Canad. Anaes. Soc. Jour. 24: 353-360 (1977).

32. Stamenkovic, L. \& Spierdijk, J. Anaesthesia in patients with phaeochromocytoma. Anaesthesia 31: 941-945 (1976).

33. Clakke, A.D., Tobias, M.A., \& Challen, P.D. The use of neuroleptanalgesia during surgery for phacochromocytoma. Br. J. Anaesth. 44: 1093-1096 (1972)

34. Bertolo, L., Novakavic, L., \& Penna, M. Antiarthythmia effects of droperidol Anesthesiology 37: $520-535$ (1972).

35. Whitwam, J.G. \& Russell, W.J. The acute cardiovascular changes and adrenergic blockade by droperidol in man. Brit. J. Anesth. 43: 581-591 (1971).

36. PUDDY. B.R. Effects of diopendol on the vasoconstriction produced by noradrenaline, histamine, sympathetic nerve stimulation and polassium in the isolated rabbit auricular artery. $\mathrm{Br}$. J. Anesth. 43: 441-444(1971). 
37. Toda, N. \& Hatano, Y. Alpha-adrenergic blocking action of fentunyl on the isolated aurta of the rabbit. Anesthesiology 46: 411-416(1977).

38. Sumikawa, K. \& Amakata, Y. The pressor effecl of droperidul on a patient with phaeochromotycoma. Anesthesiology 46: 359-361 (1977).

39. STOLitinG, R.K. Hemodynamic effects of gallamine during halothane, nitrous oxide anesthesia. Anesthesiology 39: 645 (1973).

40. Brown, B.R. \& Crout, J.R. The sympathomimetic effect of gallamine in the heart. J. Pharmacol. Exp. Ther. I72: 266-273 (1970).

41. Galindo. A. \& Davis, T. Succinylcholine and cardiac excitability. Anesthesiology 23: 32-40 (1962).

42. Mathias. J.A. \& Evans-Prosser, C.D.G. An investigation into the site of action of suxamerhonium on cardiac rhythm. Progress in Anesthesiology Proceedings of the Fourth World Congress of Anesthesiologists. Amsterdam. Excerpla Medica Foundation 1970, pp. 1153-1164.
43. KaTZ, R.I. \& Bigiger, J.T, JR. Cardiac arrhythmias during anesthesia and operation. Anesthesiology 33: 193-213 (1970).

44. Fuxnshima, K. \& Myshita, K. Histamine levels following intravenous administration of pancuronium bromide in anesthetized subjects. Symposium on pancuronium bromide. Tokyo, Japan (1960).

45. Buckett, W.R. Marjoribanks. C.E.B., Marwick. F.A. et al. The pharmocology of pancuronium bromide. Brit. J. Pharmacol. 32: 678 (1978).

46. Craco, R.M. Eckaldt, J.W. \& Wiswell. J.G. Phieochromocytoma: treatment with alphal and beta adrenergic blocking drugs. J.A.M.A. 202:807 (1967).

47. Kumar, S.M. \& Zsigmond. E.K. Anesthetic management of pheochromocytoma. Anesth. Rev. 5: 14-24 (1978). 